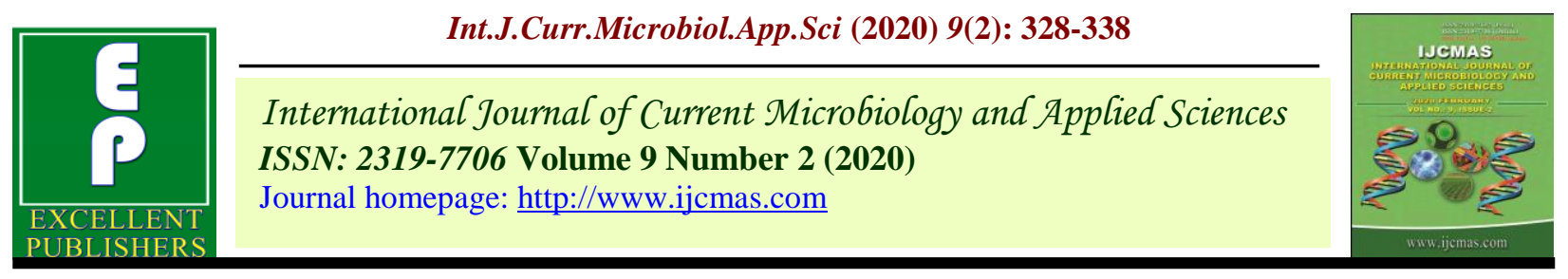

Original Research Article

https://doi.org/10.20546/ijcmas.2020.902.042

\title{
Genetic Variability Analysis of QPM (Zea mays L.) Inbreds using Morphological Characters
}

\author{
Digvijay Singh*, Ajay Kumar, Rajesh Kumar, Nitesh Kushwaha, \\ Tushar Arun Mohanty and Pooja Kumari \\ Department of Plant Breeding and Genetics, Dr. Rajendra Prasad Central Agricultural \\ University, Pusa, Samastipur (Bihar), India \\ *Corresponding author
}

\section{Keywords \\ QPM, genetic \\ variability, \\ heritability and \\ genetic advance percentage of mean.}

\section{Article Info}

Accepted:

05 January 2020

Available Online:

10 February 2020

\section{A B S T R A C T}

With the aim to assess the extent of genetic variability, heritability, genetic advance for yield and kernel quality traits in twenty five diverse QPM inbred lines. The crop was raised at Instructional Farm, Tirhut College of Agriculture, DRPCAU, Pusa, Samastipur (Bihar) during kharif 2018.The trail was set up in randomized block design with three replications having plot size of $1.5 \times 4.0=6$ $\mathrm{m}^{2}$. Analysis of variance revealed significant differences for 11 characters studied among the genotypes. The characters studied were days to $75 \%$ tasseling, days to $75 \%$ silking, days to $75 \%$ brown husk, Plant height $(\mathrm{cm})$, Ear height $(\mathrm{cm})$, Ear length $(\mathrm{cm})$, Ear girth $(\mathrm{cm})$, Tassel length $(\mathrm{cm})$, Number of kernel rows per ear, Number of kernels per row and Grain yield ( $\mathrm{Kg} / \mathrm{ha})$. Genetic variability parameter showed that phenotypic coefficient of variation (PCV) was higher than the respective genotypic coefficient of variation (GCV). High magnitude of GCV and PCV was observed for Grain yield ( $\mathrm{kg} / \mathrm{ha})$ indicating the importance of these traits in evolution and selection of inbred lines for yield improvement under maize breeding programme. Data recorded for heritability showed that high heritability accompanied with high genetic advance as percent of mean was recorded for ear length $(\mathrm{cm})$, plant height, ear height and grain yield $(\mathrm{kg} / \mathrm{ha})$ indicating effectiveness of selection due to preponderance of additive gene action and breeder may consider these traits as main selection criteria.

\section{Introduction}

Maize is one of the most important cereal crop in the world after rice and wheat. Apart from its pivotal role in world's economy and trade as a food, feed and industrial input it is widely explored as a model crop for various genetic studies. Although, a major portion of maize produced worldwide is used for animal consumption, still it caters to the need of billions of people worldwide for proteins and calories requirement, particularly, in Africa, South America and Asia. It is cultivated in a wider range of environments than wheat and rice because of its greater adaptability (Koutsika-Sotiriou, 1999). It is grown from the altitudes more than $3000 \mathrm{MSL}$ to $58^{\circ} \mathrm{N}$ to $40^{\circ} \mathrm{S}$ from below sea level and in areas with 
annual rainfall of $250 \mathrm{~mm}$ to $>5000 \mathrm{~mm}$ (Downswell et al., 1996). The area under maize is 180.64 million ha with production of 1033.6 million tones and the productivity is 5.7 tonnes/ha at global level (Annual report maize, 2018).

Maize is a low cost and rich repository of carbohydrates, fats, proteins, vitamins and minerals and therefore it is also called 'poor man's nutricereal' (Prasanna et al., 2001). Protein from cereals including normal maize, have poor nutritional value because of reduced content of essential amino-acids such as lysine and tryptophan leading to harmful consequences such as growth retardation, protein energy malnutrition, anemia, pellagra, free radical damage etc.

Normal maize varieties are deficient to two essential amino acids, lysine and tryptophan (Azevedo and Arruda, 2010; Mbuya et al., 2011). Maize mutants for high lysine and tryptophan have been reported in several studies. The lysine and tryptophan content in normal maize varieties is less than a half of the recommended rate for human nutrition (FAO/WHO-Expert consultation, 1990).

This problem has been addressed through research breakthroughs at CIMMYT in the late 1990's that lead to the development of quality protein maize (QPM) that content twice the amount of lysine and tryptophan (Krivanek et al., 2007).

Genetic improvements in traits of economic importance, along with maintaining sufficient amount of variability are always the desired objectives in maize breeding programs (Ali, 1991; Hallauer and Miranda, 1988). Genetic variability is the primary need for sound plant breeding approach for realizing higher economic yield because selection and its success would depend on the availability of wider genetic variability.
Therefore, an assessment of genetic variability is a pre-requisite for basic step in breeding and essential for genetic improvement of any character. It is well known that high heritability estimates coupled with high genetic advance provide a great scope for making efficient selection among the different existing lines.

Information on the genetic parameters such as coefficient of variation, heritability, genetic advance and the influence of environment on the expression of yield and yield components will help the breeder to evolve suitable cultivars within short time. Therefore, keeping this back ground in view, the present study was undertaken to analyze the variance, genetic variability, heritability, genetic gain among 25 elite genotypes of maize.

\section{Materials and Methods}

The present investigation was carried out at the Instructional Farm, Tirhut College of Agriculture, DRPCAU, Pusa, Samastipur (Bihar) during kharif 2018. The nucleus seed of twenty five genotypes of high quality protein maize were obtained from AICRP, Dholi (Table-1).

Twenty five diverse genotypes were raised in randomized block design with three replications having plot size of $1.5 \times 4.0=6$ $\mathrm{m}^{2}$. Each plot consisting of two rows of $4 \mathrm{~m}$ length spaced at $75 \mathrm{~cm}$ row to row and $20 \mathrm{~cm}$ plant to plant, respectively. All the recommended package of practices were applied to raise a good and healthy crop. The data were recorded on five randomly selected plant samples from each replication for different quantitative characters, viz. plant height, Ear height, days to $75 \%$ tasseling, days to $75 \%$ silking, days to $75 \%$ brown husk, Tassel length, ear length, ear diameter, No. of kernel rows per ear, No. of kernels per row and Grain yield (kg/ha). 
Table.1 List of the Materials and their Source

\begin{tabular}{|c|c|c|c|}
\hline S.No. & Inbred lines & Abbreviation & Source \\
\hline 1. & $\begin{array}{l}\text { [CL-G2501*CML170]-B-2-2-2-B-1-1- } \\
\text { BBB-\# }\end{array}$ & CLG-2501-170 & AICRP,Dholi Centre \\
\hline 2. & CML161*165-18-2-1-2-BBB-\# & CML61*65-18 & AICRP,Dholi Centre \\
\hline 3. & CML161*165-50-1-3-B*4-\# & CML61*65-50 & AICRP,Dholi Centre \\
\hline 4. & (CML161*165)-F2-21-3-1-B*5-\# & CML61*65-21 & AICRP,Dholi Centre \\
\hline 5. & (CML176*CLG2501)-B-55-1-5-2-BBB-\# & CML*CLG-55 & AICRP,Dholi Centre \\
\hline 6. & $\begin{array}{l}\text { (CML165*CL-02843)-B-12-2-4-B-3-BBB- } \\
\#\end{array}$ & CML*CL02843-12 & AICRP,Dholi Centre \\
\hline 7. & $\begin{array}{l}\text { (CLQ-6601*CL-02843)-B-23-2-1-B-1- } \\
\text { BBB-\# }\end{array}$ & CLQ*CL-23 & AICRP,Dholi Centre \\
\hline 8. & $\begin{array}{l}\text { (CLQ-6601*CL-02843)-B-26-1-1-BB-1- } \\
\text { B*6-\# }\end{array}$ & CLQ*CL-26 & AICRP,Dholi Centre \\
\hline 9. & P70C0-BBB-6-B*6-\# & P70C0-6 & AICRP,Dholi Centre \\
\hline 10. & CLQ-RCYQ28-B-3-B*6-\# & CLQ-RCYQ-28 & AICRP,Dholi Centre \\
\hline 11. & CLQ-RCYQ41-BB-2-B*6-\# & CLQ-RCYQ-41 & AICRP,Dholi Centre \\
\hline 12. & CLQ-RCYQ035-B*11-\# & CLQ-RCYQ-035 & AICRP,Dholi Centre \\
\hline 13. & CLQ-RCYQ12-B-1-B*6-\# & CLQ-RCYQ-12 & AICRP,Dholi Centre \\
\hline 14. & CML161*165-3-2-3-B*4-\#-B1 & CML61*65-B*4 & AICRP,Dholi Centre \\
\hline 15. & G34QC24-BBB-16-B*8-\#-B & G34QC-BB-16 & AICRP,Dholi Centre \\
\hline 16. & POO117C8(TEYFQPM)-B-117-B*10 & POO-TEYFQM & AICRP,Dholi Centre \\
\hline 17. & CML161*165-16-2-1-B*10 & CML61*65-16 & AICRP,Dholi Centre \\
\hline 18. & G33QMH103-3-1-5-1-B*14 & G33QMH-103 & AICRP,Dholi Centre \\
\hline 19. & (CML176*CLG2501)-B-55-1-2-B*4 & CML76*CLG-B*4 & AICRP,Dholi Centre \\
\hline 20. & CLQRCYQ44-B*4-1-\#-B & CLQ-RCYQ-44 & AICRP,Dholi Centre \\
\hline 21. & CML161-1-B*8-\#-B & CML61-B*8 & AICRP,Dholi Centre \\
\hline 22. & CML451Q-B*8 & CML451-B*8 & AICRP,Dholi Centre \\
\hline 23. & CML165-B*9-\# & CML65-B*9 & AICRP,Dholi Centre \\
\hline 24. & CML193-B*6-\# & CML93-B*6 & AICRP,Dholi Centre \\
\hline 25. & ( CML161*CLQ-RCYQ31)-B-22-2-B*5 & CML61*CLQ-B*5 & AICRP,Dholi,Centre \\
\hline
\end{tabular}

Out of the 11 quantitative characters, days to $75 \%$ tasseling, days to $75 \%$ silking and days to $75 \%$ brown husk were recorded on plot basis. Rest of the traits were recorded on the basis of five randomly chosen plants at appropriate stage. The data recorded on different characters were statistically analyzed using software WINDOSTAT version 7.0 developed by Indostat Services Ltd., Hyderabad, India. The analysis of variance for Randomized Block Design was carried out on the basis of the model described by Panse and Sukhatme (1985) for individual characters. To estimate the extant of magnitude of variation among examined traits, all data were analyzed according to Singh and Chaudhary (1985). For estimation of variance components viz., phenotypic variances $\left(\sigma^{2} p\right)$ and genotypic variances $\left(\sigma^{2} g\right)$ both were estimated using the following formula as suggested by Panse and Sukhatme (1967). 


\section{Results and Discussion}

Success of a breeding programme largely depends on the extent of genetic variability present in the material, greater the diversity in the material better the chances for evolving promising and desired types. Phenotypic variability expressed by a genotype or a group of genotypes in any species can be partitioned into genotypic and phenotypic components.

The genotypic components being the heritable part of the total variability, its magnitude for yield and related characters influence the selection strategies to be adopted by the breeders. Morphological markers differ among species, genus and varieties of plants. It is the easiest and quickest way to identify or detect the variation in morphological traits for improvement (Bagali et al., 2010).
However, these traits are largely affected by environmental variations until and unless these are studied minutely over locations and variable environmental conditions viz., temperature and climate.

\section{Analysis of variance}

The analysis of variance for the design of an experiment (Table 2) indicated the existence of significant variability among the 25 genotypes of maize for all the characters under study. The presence of large amount of variability is due to diverse source of the material as well as environmental influence, which pre-dominantly governed the phenotype.

Table.2. Analysis of variance for eleven characters in QPM inbred lines

\begin{tabular}{|c|c|c|c|c|}
\hline \multirow[t]{2}{*}{ S.No. } & \multirow{2}{*}{$\begin{array}{l}\text { Source of Variation } \\
\text { Characters }\end{array}$} & \multicolumn{3}{|c|}{ Mean sum of squares } \\
\hline & & $\begin{array}{c}\text { Replication } \\
\quad(\mathbf{d f}=2)\end{array}$ & $\begin{array}{c}\text { Treatment } \\
(\mathbf{d f}=\mathbf{2 4})\end{array}$ & $\begin{array}{c}\text { Error } \\
(d f=48)\end{array}$ \\
\hline 1 & Plant Height $(\mathrm{cm})$ & 130.54 & $808.73 * *$ & 111.14 \\
\hline 2 & Ear Height $(\mathrm{cm})$ & 22.48 & $316.72 * *$ & 25.5 \\
\hline 3 & Days to $75 \%$ tasseling & 51.25 & $29.98 * *$ & 5.98 \\
\hline 4 & Days to $75 \%$ silking & 44.01 & $25.22 * *$ & 3.99 \\
\hline 5 & Days to $75 \%$ Brown husk & 7.41 & $9.05^{* *}$ & 3.98 \\
\hline 6 & Tassel length $(\mathrm{cm})$ & 0.68 & $18.65 * *$ & 5.06 \\
\hline 7 & Ear length $(\mathrm{cm})$ & 4.79 & $16.25 * *$ & 1.18 \\
\hline 8 & Ear girth $(\mathrm{cm})$ & 4.40 & $3.60 * *$ & 1.02 \\
\hline 9 & No. of kernel rows per ear & 1.51 & $3.56 * *$ & 2.90 \\
\hline 10 & No. of kernels per row & 12.77 & $26.48 * *$ & 8.02 \\
\hline 11 & Grain yield (kg/ha) & 106247.10 & $794520.29 * *$ & 82309.70 \\
\hline
\end{tabular}

** Significant at $\mathrm{P}=0.01$ 
The variability was highly significant for grain yield ( $\mathrm{kg} / \mathrm{ha}$ ) followed by plant height, ear height, days to $75 \%$ tasseling, No. of kernels per row, days to $75 \%$ silking, tassel length, ear length. Existence of these significant differences amongst the inbred lines indicated the presence of considerable phenotypic and genotypic differences.

Thus, the presence of variability in present investigation indicated the ample scope of selection for these traits. It is apparent that differences among the inbred lines were observed due to differences in the genes carried by different genotypes and interaction of different gene combinations possessed by different inbred lines with the environment to which the genotypes were exposed.

The difference in magnitude of phenotypic and genotypic variance among all eleven characters indicated that environment have played some role in the expression of characters. These results are in accordance with the results of Om Prakash et al., (2006), Singh and Jamwal (2009), Umar et al., (2016), Beulah etal., (2018).

Table.3.1 Mean, range and coefficient of variation for various characters in QPM inbred lines

\begin{tabular}{|c|c|c|c|c|c|c|}
\hline \multirow[t]{2}{*}{ S.No. } & \multirow[t]{2}{*}{ Character } & \multirow[t]{2}{*}{ Mean } & \multirow[t]{2}{*}{ S.E } & \multicolumn{2}{|c|}{ Range } & \multirow[t]{2}{*}{ C.V } \\
\hline & & & & Min & Max & \\
\hline 1 & Plant Height (cm) & $120.59 \pm 6.08$ & 6.08 & 93.33 & 145.16 & 8.74 \\
\hline 2 & Ear Height $(\mathrm{cm})$ & $55.17 \pm 2.91$ & 2.91 & 32.50 & 77.50 & 9.15 \\
\hline 3 & $\begin{array}{l}\text { Days to } 75 \% \\
\text { Tasseling }\end{array}$ & $56.17 \pm 1.28$ & 1.28 & 49.33 & 60.66 & 3.97 \\
\hline 4 & Days to $75 \%$ Silking & $59.33 \pm 1.15$ & 1.15 & 53.66 & 63.66 & 3.36 \\
\hline 5 & $\begin{array}{l}\text { Days to } 75 \% \text { Brown } \\
\text { Husk }\end{array}$ & $93.77 \pm 1.15$ & 1.15 & 90.00 & 97.00 & 2.12 \\
\hline 6 & Tassel length $(\mathrm{cm})$ & $28.82 \pm 1.29$ & 1.29 & 24.03 & 32.53 & 7.80 \\
\hline 7 & Ear length (cm) & $17.25 \pm 0.62$ & 0.62 & 13.43 & 22.58 & 6.29 \\
\hline 8 & Ear girth $(\mathrm{cm})$ & $12.71 \pm 0.58$ & 0.58 & 11.23 & 15.78 & 7.96 \\
\hline 9 & $\begin{array}{l}\text { No. of kernel } \\
\text { rows/ear }\end{array}$ & $13.60 \pm 0.98$ & 0.98 & 12.00 & 16.23 & 12.50 \\
\hline 10 & No. of kernels /row & $29.29 \pm 1.63$ & 1.63 & 24.16 & 35.66 & 9.67 \\
\hline 11 & Grain yield (kg/ha) & $2105.38 \pm 165.63$ & 165.63 & 1211.75 & 3081.55 & 13.62 \\
\hline
\end{tabular}


Table.3.2 Mean performance of twenty five QPM inbreds for eleven characters

\begin{tabular}{|c|c|c|c|c|c|c|c|c|c|c|c|}
\hline $\begin{array}{l}\text { Genotyp } \\
\text { es }\end{array}$ & $\begin{array}{l}\text { Plant } \\
\text { Height } \\
\text { (cm) }\end{array}$ & $\begin{array}{l}\text { Ear } \\
\text { Height } \\
\text { (cm) }\end{array}$ & $\begin{array}{l}\text { Day to } 75 \\
\% \\
\text { Tasseling }\end{array}$ & $\begin{array}{l}\text { Day to } \\
75 \% \\
\text { silking }\end{array}$ & $\begin{array}{l}\text { Day to } 75 \\
\text { \% Brown } \\
\text { husk }\end{array}$ & $\begin{array}{l}\text { Tassel } \\
\text { length } \\
(\mathrm{cm})\end{array}$ & $\begin{array}{l}\text { Ear } \\
\text { length } \\
(\mathrm{cm})\end{array}$ & $\begin{array}{l}\text { Ear } \\
\text { girth } \\
\text { (cm) }\end{array}$ & $\begin{array}{l}\text { No. of } \\
\text { kernel } \\
\text { rows/Ear }\end{array}$ & $\begin{array}{l}\text { No. of } \\
\text { kernels/ } \\
\text { Row }\end{array}$ & $\begin{array}{l}\text { Grain yield } \\
\text { (kg/ha) }\end{array}$ \\
\hline 1 & 145.16 & 57.83 & 51.33 & 55.00 & 90.33 & 27.15 & 19.51 & 13.36 & 13.00 & 32.00 & 2509.17 \\
\hline 2 & 144.16 & 55.66 & 58.00 & 60.66 & 94.33 & 28.73 & 18.98 & 14.75 & 12.33 & 31.33 & 2378.97 \\
\hline 3 & 93.33 & 32.50 & 55.66 & 59.33 & 93.33 & 28.66 & 13.78 & 11.33 & 12.00 & 24.16 & 1211.75 \\
\hline 4 & 141.83 & 59.60 & 54.33 & 58.00 & 93.33 & 31.36 & 16.01 & 12.85 & 12.66 & 29.83 & 1868.93 \\
\hline 5 & 112.83 & 55.16 & 60.66 & 63.33 & 95.66 & 29.78 & 16.41 & 12.30 & 13.33 & 27.83 & 1584.68 \\
\hline 6 & 97.83 & 50.26 & 56.00 & 60.33 & 94.66 & 32.53 & 18.51 & 12.23 & 12.50 & 24.56 & 1426.25 \\
\hline 7 & 124.16 & 55.90 & 49.33 & 53.66 & 90.00 & 30.38 & 18.23 & 13.33 & 14.23 & 33.16 & 2944.07 \\
\hline 8 & 118.66 & 56.66 & 59.33 & 61.00 & 94.00 & 32.26 & 16.20 & 11.23 & 13.56 & 30.66 & 2130.84 \\
\hline 9 & 113.66 & 48.33 & 53.33 & 56.33 & 92.33 & 29.26 & 16.15 & 11.96 & 14.43 & 33.00 & 2834.82 \\
\hline 10 & 118.53 & 52.26 & 58.00 & 61.66 & 94.33 & 27.48 & 22.58 & 15.78 & 13.06 & 27.33 & 3081.55 \\
\hline 11 & 116.83 & 53.83 & 53.66 & 57.33 & 93.33 & 32.21 & 18.18 & 12.41 & 13.76 & 28.50 & 1754.90 \\
\hline 12 & 97.16 & 48.00 & 54.66 & 56.66 & 93.66 & 24.13 & 17.38 & 12.85 & 12.53 & 35.66 & 2431.90 \\
\hline 13 & 122.10 & 53.33 & 52.66 & 56.00 & 91.66 & 24.03 & 13.43 & 11.26 & 13.06 & 28.16 & 1534.50 \\
\hline 14 & 108.33 & 42.26 & 59.66 & 63.00 & 94.33 & 29.05 & 15.55 & 12.40 & 15.43 & 25.00 & 2229.94 \\
\hline 15 & 100.50 & 43.40 & 55.33 & 58.33 & 93.00 & 29.21 & 14.15 & 12.20 & 13.56 & 26.83 & 1568.00 \\
\hline 16 & 122.66 & 50.16 & 57.33 & 59.33 & 94.33 & 25.43 & 18.36 & 11.90 & 16.23 & 25.50 & 2298.06 \\
\hline 17 & 143.26 & 68.56 & 59.66 & 62.33 & 95.66 & 32.13 & 16.25 & 14.15 & 14.00 & 26.83 & 1609.39 \\
\hline 18 & 97.90 & 50.03 & 58.00 & 61.66 & 94.66 & 28.13 & 14.16 & 12.70 & 14.20 & 29.66 & 1829.91 \\
\hline 19 & 115.10 & 48.50 & 53.33 & 56.66 & 93.00 & 28.76 & 19.18 & 11.96 & 13.56 & 27.50 & 1658.31 \\
\hline 20 & 136.73 & 75.60 & 60.33 & 63.66 & 95.33 & 29.30 & 16.78 & 14.16 & 12.86 & 29.66 & 1927.13 \\
\hline 21 & 111.00 & 58.66 & 54.33 & 57.33 & 93.00 & 26.31 & 16.88 & 12.86 & 13.36 & 30.66 & 2123.70 \\
\hline 22 & 139.03 & 77.50 & 52.33 & 56.00 & 91.33 & 29.61 & 20.60 & 12.38 & 16.00 & 29.50 & 2347.11 \\
\hline 23 & 119.16 & 49.76 & 58.66 & 62.00 & 96.00 & 30.93 & 21.43 & 13.25 & 14.40 & 33.33 & 2988.23 \\
\hline 24 & 141.00 & 68.36 & 60.33 & 62.66 & 97.00 & 28.98 & 16.06 & 12.51 & 12.53 & 31.50 & 2326.78 \\
\hline 25 & 133.83 & 67.10 & 58.00 & 61.00 & 95.66 & 24.61 & 16.63 & 11.76 & 13.53 & 30.16 & 2035.640 \\
\hline Mean & 120.59 & 55.17 & 56.17 & 59.33 & 93.77 & 28.82 & 17.25 & 12.71 & 13.60 & 29.29 & 2105.38 \\
\hline $\operatorname{SEm}( \pm)$ & 6.08 & 2.91 & 1.28 & 1.15 & 1.15 & 1.29 & 0.62 & 0.58 & 0.98 & 1.63 & 165.63 \\
\hline CD $5 \%$ & 17.30 & 8.28 & 3.66 & 3.27 & 3.27 & 3.69 & 1.78 & 1.66 & 1.71 & 4.65 & 470.99 \\
\hline
\end{tabular}




\begin{tabular}{|l|l|l|l|r|l|r|l|l|l|}
\hline $\mathbf{1}$ & $\begin{array}{l}\text { CLG-2501- } \\
\mathbf{1 7 0}\end{array}$ & $\mathbf{6}$ & $\begin{array}{l}\text { CML*CL0284 } \\
\mathbf{3 - 1 2}\end{array}$ & $\mathbf{1 1}$ & $\begin{array}{l}\text { CLQ-RCYQ- } \\
\mathbf{4 1}\end{array}$ & $\mathbf{1 6}$ & $\begin{array}{l}\text { POO- } \\
\text { TEYFQM }\end{array}$ & $\mathbf{2 1}$ & CML61-B*8 \\
\hline $\mathbf{2}$ & CML61*65-18 & 7 & CLQ*CL-23 & 12 & $\begin{array}{l}\text { CLQ-RCYQ- } \\
035\end{array}$ & 17 & CML61*65-16 & 22 & CML451-B*8 \\
\hline $\mathbf{3}$ & CML61*65-50 & 8 & CLQ*CL-26 & 13 & $\begin{array}{l}\text { CLQ-RCYQ- } \\
12\end{array}$ & 18 & G33QMH-103 & 23 & CML65-B*9 \\
\hline $\mathbf{4}$ & CML61*65-21 & 9 & P70C0-6 & 14 & $\begin{array}{l}\text { CML61*65- } \\
\text { C*4 }\end{array}$ & 19 & $\begin{array}{l}\text { CML76*CLG- } \\
\text { B*4 }\end{array}$ & 24 & CML93-B*6 \\
\hline $\mathbf{5}$ & CML*CLG-55 & 1 & CLQ-RCYQ-28 & 15 & $\begin{array}{l}\text { G34QC-BB- } \\
16\end{array}$ & 20 & CLQ-RCYQ-44 & 25 & $\begin{array}{l}\text { CML61*CLQ- } \\
\text { CM*5 }\end{array}$ \\
\hline
\end{tabular}

Table.4 Genetic parameters, Heritability and Genetic advance as per cent of mean of various characters in QPM inbred lines

\begin{tabular}{|c|c|c|c|c|c|c|c|}
\hline S.No. & Characters & $\sigma_{g}^{2}$ & $\sigma_{p}^{2}$ & GCV & PCV & $\begin{array}{c}h^{2}(\text { Broad } \\
\text { sense) \% }\end{array}$ & $\begin{array}{c}\text { GA as } \% \text { of } \\
\text { Mean }\end{array}$ \\
\hline 1 & $\begin{array}{l}\text { Plant Height } \\
(\mathrm{cm})\end{array}$ & 232.53 & 343.67 & 12.64 & 15.37 & 68 & 21.42 \\
\hline 2 & Ear Height $(\mathrm{cm})$ & 97.08 & 122.57 & 17.86 & 20.07 & 79 & 32.74 \\
\hline 3 & $\begin{array}{l}\text { Days to } 75 \% \\
\text { Tasseling }\end{array}$ & 8.33 & 13.31 & 5.84 & 6.49 & 63 & 8.37 \\
\hline 4 & $\begin{array}{l}\text { Days to } 75 \% \\
\text { Silking }\end{array}$ & 7.08 & 11.06 & 4.48 & 5.61 & 64 & 7.38 \\
\hline 5 & $\begin{array}{l}\text { Days to } 75 \% \\
\text { Brown Husk }\end{array}$ & 1.69 & 5.67 & 1.39 & 2.54 & 30 & 1.55 \\
\hline 6 & $\begin{array}{l}\text { Tassel length } \\
(\mathrm{cm})\end{array}$ & 4.53 & 9.59 & 7.38 & 10.75 & 47 & 10.44 \\
\hline 7 & Ear length $(\mathrm{cm})$ & 5.02 & 6.20 & 12.99 & 14.43 & 81 & 24.07 \\
\hline 8 & Ear girth $(\mathrm{cm})$ & 0.86 & 1.88 & 7.28 & 10.79 & 45 & 10.11 \\
\hline 9 & $\begin{array}{l}\text { No. of kernel } \\
\text { rows/Ear }\end{array}$ & 0.22 & 3.12 & 3.45 & 12.97 & 07 & 1.89 \\
\hline 10 & $\begin{array}{l}\text { No. of kernels } \\
\text { /row }\end{array}$ & 6.15 & 14.18 & 8.46 & 12.85 & 43 & 11.48 \\
\hline 11 & $\begin{array}{l}\text { Grain yield } \\
(\mathrm{kg} / \mathrm{ha})\end{array}$ & 237403.5 & 319713.2 & 23.14 & 26.86 & 74 & 41.08 \\
\hline
\end{tabular}

\section{Mean performance (Mean table)}

A perusal of the data on mean values of twenty five maize inbred lines (Table-3.1 and 3.2) indicates Mean performance of different inbred lines revealed that the best inbred line for grain yield (Kg/ha) was CLQ-RCYQ-28. It was highest yielder having superior in ear length, ear girth and having moderate no. of kernel rows per ear followed by CML65-B*9 and the inbred line CML61-65-18 showed lowest in grain yield among all inbred lines. The best inbred lines for anthesis-silk interval showed early in days to $75 \%$ tasseling and silking were CML-373 (55.67, 58.67) whereas the inbred line WNC DMR $11 \mathrm{R}$ $4776(60.33,64.00)$ showed very late anthesis- silk interval among all inbred lines. The best inbred line for early in days to $75 \%$ brown husk was CLQ*CL-23 and inbred line CML93-B*6 (97.00) was late in days to $75 \%$ brown husk among all other inbred lines. 
The best inbred line for dwarf in plant height was CML61*65-50 and inbred CLG2501-170 was tallest among inbred lines. The best inbred lines for significantly lower ear height was $161 * 65-18$ and inbred line CML451-B*8 showed higher ear height among rest of inbred lines.

The best inbred line for maximum ear length was CLQ-RCYQ-28 and inbred line CLQRCYQ-12 showed minimum in ear length among all other inbred lines. The best inbred line for maximum in ear girth was CLQRCYQ-28 (15.78 cm) and inbred line CLQCL-26 showed minimum ear girth among the inbred lines.

The best inbred line for maximum in number of kernel rows per ear were POO TEYFQM followed by CML451-B*8, CML61*65-B*4 and the inbred line CML61*65-50 showed minimum number of kernel rows per ear among all inbred lines. The best inbred lines for maximum number of kernels per row was CLG-2501-170 followed by CML61*65-18 and inbred line CML61*65-50 showed minimum number of kernels per row among all the inbreds.

\section{Genetic variability for yield and component traits}

Environment has great influence on many quantitative and qualitative traits of plants. This influence showed heritable and nonheritable variation, which can be estimated by the parameters like genotypic coefficient of variation $(\mathrm{GCV})$, heritability and genetic gain. Mean standard error, range, genotypic coefficient of variation (GCV), phenotypic coefficient of variation (PCV), heritability in broad sense and genetic gain as percentage of mean were given in (Table 4). For all the eleven characters phenotypic variance was higher than its corresponding genotypic variance.
This may be due to non-genetic factor which played some role in manifestation of these characters. High genotypic coefficient of variation and high phenotypic coefficient of variation were recorded for grain yield ( $\mathrm{kg} / \mathrm{ha})$ indicating the importance of these traits in evolution and selection of inbred lines.

Characters having moderate genotypic coefficient of variability was recorded for ear height $(\mathrm{cm})$, ear length $(\mathrm{cm})$, plant height (cm) and moderate phenotypic coefficient of variation were recorded for plant height $(\mathrm{cm})$, ear height $(\mathrm{cm})$, number of kernel rows per ear and number of kernels per rows ,ear length $(\mathrm{cm})$,tassel length $(\mathrm{cm})$, ear girth $(\mathrm{cm})$.

The present findings are in accordance with the earlier findings of Om Prakash et al., (2006), Choudhari and prodhan (2007), Murugan et al., (2010), Shanthi et al., (2011), Bharathiveeramani et al., (2012) Hepziba et al., (2013), Sharma et al., (2014) and Umar et al., (2016) in maize.

\section{Heritability and Genetic advance}

Heritability and genetic advance were regarded as important selection parameters. Genetic variation along with heritability estimates would give a better idea about the efficiency of selection. Heritability measures transmission of hereditary values from parent to their offspring. It is most important factor that determines the genetic improvement or response to selection.

The estimates of heritability help the plant breeder in selection of elite characters from diverse genetic populations. The higher value of the heritability estimates are advantageous where improvement is sought through phenotypic selection. Genetic advance is the improvement in mean genotypic value of selected plants over the parental population. 
High heritability was recorded for ear length, ear height, grain yield ( $\mathrm{kg} / \mathrm{ha})$, Plant height, days $75 \%$ silking and days $75 \%$ tasseling. Characters having moderate heritability were recorded for days to $75 \%$ brown husk, tassel length, ear girth and No. of kernels per row. However, low heritability was recorded for number of kernel rows per ear.

Similar findings were recorded by Aboyi et al., (2004), Om Prakash et al., (2006), Sumalini and Manjulatha (2012), Vashistha et al., (2013), Kumar et al., (2014) in maize. High heritability accompanied with low genetic advance as percent of mean was observed for days to $75 \%$ tasseling and days to $75 \%$ silking indicated that most likely heritability is due to non-additive gene action and the high heritability was being exhibited due to favourable influence of environment rather than genotypes and selection for these traits may not be rewarding. Similar finding were recorded for these characters in maize by Kumar et al., (2014).

Low heritability coupled with low genetic advance was recorded for Number of kernel rows per ear and days to $75 \%$ brown husk indicates that the character is highly influenced by environmental effects and selection would be ineffective. Similar results were obtained by Murugan et al., (2010) in maize.

\section{Acknowledgment}

The authors are grateful to Tirhut College of Agriculture, DRPCAU, Pusa, Samastipur for supporting part of this research.

\section{References}

Abhirami, S., Vanniarajan, C. and Arumugachamy, S. (2005). Genetic variability studies in maize (Zea mays) germplasm. Plant Archives. 5(1): 105-
108.

Aboyi, I.K., Ojo, A.A., Kalu, B.A. and Adeyemo, M.O. (2004). Genetic variability, heritability and genetic advance in progenies of extra-early and early maize (Zea mays L.) populations. Journal of Sustainable Agricultural and Environment .6(2): 179-184.

Al-Jibouri, H., Miller, P.A. and Robinson, H.F. (1958). Genotypic and environmental variances and covariance in an upland cotton cross of interspecific origin. Agronomy Journal, 50(10): 633-636.

Allard, R.W. (1960). Principles of Plant Breeding. John Niley and Sons Inc., New York.

Anonymous, (2014-15) Directorate of Maize Research, Pusa Campus, New Delhi 110012 , pp. 82.

Azevedo, R.A. and Arruda, P. (2010). High lysine maize: the key discoveries that have made it possible. Amino Acids, 39: 979-989.

Azevedo, R.A., Lea, P.J., Damerval, C., Landry, J., Bellato, C.M., Meinhardt, L.W., Le Guilloux, M., Delhaye, S., Varisi, V.A., Gaziola, S.A., Gratao, P.L. and Toro, A.A. (2004). Regulation of lysine metabolism and endosperm protein synthesis by the opaque- 5 and opaque-7 maize mutations. J. Agric. Food Chemistry. 52: 4865-4871.

Barua, N.S., Chaudhary, V.P. and Hazarika, G.N. (2017). Genetic variability and correlation studies for morphological traits in maize (Zea mays L.) genotypes. Indian Research Journal of Genetics and Biotechnology. 9(1): 38-48.

Bello, O. B., Ige, S. A., Azeez, M. A., Afolabi, M. S., Abdulmaliq, S.Y. and Mohamood, J. (2012). Heritability and genetic advance for grain yield and its component characters in maize (Zea mays L.) International Journal of Plant Research. 2(5): 138-145 
Beulah, G., Marker, S. and Rajasekhar, D. (2018). Assessment of quantitative genetic variability and character association in maize (Zea mays L.), Journal of Pharmacognosy and Phytochemistry. 7(1): 2813-2816.

Bharathibveeramani, B., Prakash, M. and Sestharam, A. (2012). Variability studies of quantitative characters in Maize (Zea mays L.), Electronic Journal of Plant Breeding. 3(4): 995997.

Choudhuri, A. and Prodhan, H.S. (2007). Genetic variability and character association in baby corn. Journal of Environment and Ecology. 25 (4) 881884

Hemavathy, A.T., Balaji, K., Ibrahim, S.J., Anand, G. and Deepa, S. (2008). Genetic variability and correlation studies in maize (Zea mays L.). Agricultural Science Digest. 28(2) 112114.

Jawaharlal, J., Reddy, G.L. and Kumar, R.S. (2011).Genetic variability and character association studies in maize. Agricultural Science Digest. 31(3) 199123.

Koutsika-Sotiriou M (1999). Hybrid seed production in maize. In Basra, A. S. (2ed) "Heterosis and Hybrid Seed Production in Agronomic Crops", Food Products.

Kumar, P.G., Reddy, N.V., Kumar, Sudheer. and Rao, V.P. (2014). Genetic variability, heritability and genetic advance studies in newly developed maize genotypes (Zea mays L.). International Journal of pure and applied Bioscience. 2(1) 272-275.

Lush, J.L. (1949). Heritability of quantitative characters in farm animals. Proceedings of 8th Congress of Genetics and Heriditas. 35 356-375.

Maruthi, R.T.M. and Rani, K.J. (2015). Genetic variability, heritability and genetic advance estimates in maize (Zea mays L.) inbred lines. Journal of Applied and Natural Science. 7(1): 149154.

Mohan, L. and Dhirendra, S. (2014). Studies of variability using morphological and quality traits in quality protein maize (Zea mays L.).Electronic Journal of Plant breeding. 3(5).

Murugan, S., Padmanaban, J. and Manirajan, S. (2010). Genetic variability and heritability studies in F2 and F3 generations of QPM and Non-QPM maize crosses. International Journal of Plant Sciences, Muzaffarnagar. 5(1) 290-293.

Najeeb, S.O.F.I., Rather, A.G., Parray, G.A., Sheikh, F.A. and Razvi, S.M. (2009). Studies on genetic variability, genotypic correlation and path coefficient analysis in maize under the high altitude temperate conditions of Kashmir. Maize Genetics Cooperation Newsletter. 83(3): 46-53.

Om Prakash, Shanthi, P., Satyanarayana, E. and Saikumar, R. (2006). Studies on genetic variability exploitation for quality traits and agronomic characters on quality protein maize (QPM) germplasm (Zea mays L.). Annals of Agricultural Research. 27(2): 147-153.

Panse, V.G. and Sukhatme, P.V. (1967). Statistical methods of Agricultural Research Works.III edition, ICAR, New Delhi. PP.146

Prasanna, B.M., Vasal, S.K., Kassahun, B. and Singh, N.N. (2001). Quality protein maize. Current Scencei. 81: 1308-1319.

Rajesh, V., Kumar, S., Reddy, V.N. and Sankar, A.S. (2013). Studies on Genetic Variability, Heritability and Genetic advance estimate in newly developed maize Viii genotypes. International Journal of applied Biology and Pharmaceutical Technology. 4(4): 242245. 
Shanthi, P., Satyanarayana, E., Babu, G.S. and Kumar, R.S. (2011). Studies on genetic variability for phenological, yield and quality parameters in quality protein maize (QPM) (Zea mays L.). Crop Research Hissar. 41(3): 188- 191

Sharma, R., Maloo, S.R. and Joshi, A. (2014). Genetic variability analysis in diverse maize genotypes (Zea mays L.). Electronic Journal of Plant Breeding. 5(3): 545-551.

Sumathi, P., Nirmalakumari, A. and Mohanraj, K. (2005). Genetic variability and traits interrelationship studies in industrially utilized oil rich CIMMYT lines of maize (Zea mays $L$ ). Madras Agric. J. 92(10-12): 612 - 617.
Surender, K., Chouhan and Jitendra M. (2010). Estimates of variability heritability and genetic advance in baby corn. Indian journal of Horticultural sciences. 67: 238- 241.

Umar, U.U., Abdulrahman, M.D. and Abdullahi, S. (2016). Assessment of genetic variability of maize inbred lines and their hybrids under normal and drought conditions. Nigeria Agricultural Journal. 46(2): 82-88.

Vashistha, A., Dixit, N.N., Sharma, S.K. and Marker, S. (2013). Studies on heritability and genetic advance estimate in maize genotypes. Bioscience Discovery. 4(2): 165-168.

\section{How to cite this article:}

Digvijay Singh, Ajay Kumar, Rajesh Kumar, Nitesh Kushwaha, Tushar Arun Mohanty and Pooja Kumari. 2020. Genetic Variability Analysis of QPM ( Zea mays L.) Inbreds using Morphological Characters. Int.J.Curr.Microbiol.App.Sci. 9(02): 328-338. doi: https://doi.org/10.20546/ijcmas.2020.902.042 